\title{
Merocyanine Dye-Sensitization of Polythiophene in a Conjugated Polymer/TiO 2 p-n Hetero-Junction Solar Cell
}

\author{
Kiyoaki Imoto, Kohshin Takahashi, ${ }^{* \dagger}{ }^{\dagger}$ Takahiro Yamaguchi, ${ }^{\dagger}$ Teruhisa Komura, ${ }^{\dagger}$ \\ Jun-ichi Nakamura, ${ }^{\dagger \dagger},{ }^{*}$ and Kazuhiko Murata ${ }^{\dagger \dagger}$ \\ Division of Innovative Technology and Science, Graduate School of Natural Science and Technology, \\ Kanazawa University, Kodatsuno, Kanazawa 920-8667 \\ $\dagger$ Department of Chemistry and Chemical Engineering, Faculty of Engineering, Kanazawa University, \\ Kodatsuno, Kanazawa 920-8667 \\ $\dagger$ Performance Chemicals and Materials Research Center, Nippon Shokubai Co., Ltd., \\ 5-8, Nishi Otabi-cho, Suita, Osaka, 564-8512
}

Received May 1, 2003; E-mail: ktakaha@t.kanazawa-u.ac.jp

In the blended solid of merocyanine (MC) and polythiophene (PTh)/ $\mathrm{TiO}_{2} \mathrm{p}-\mathrm{n}$ hetero-junction solar cells, a holetransfer from the excited state of MC to the ground-state of PTh accelerated the charge separation in the depletion layer formed at the $\mathrm{TiO}_{2} / \mathrm{MC}+\mathrm{PTh}$ interface, enhancing the photovoltaic properties. That is, the blended solar cell is not a so-called Grätzel cell being sensitized by mono-layer dyes chemically adsorbed on the $\mathrm{TiO}_{2}$ electrode, but rather the enhanced photovoltaic properties are attributable to the dye-sensitization of the conjugated polymer.

\begin{abstract}
Although organic solar cells have been expected to provide low-cost energy-conversion devices, practical use of them has not been achieved. Tang attained an energy conversion efficiency up to $1 \%$ by using a phtalocyanine/perylene derivative p-n junction cell. ${ }^{1}$ Recently, conjugated polymer photovoltaics have been extensively studied. For example, Friend et al. attained an energy conversion efficiency up to $1.9 \%$ by a poly[5-(2-ethylhexyloxy)-1,4-phenylenvinylene]/polythiophene double-layer solar cell using soluble conjugated polymers under AM1.5 illumination, ${ }^{2}$ Sariciftci et al. attained an energy conversion efficiency up to $3.3 \%$ in a p-n hetero-bulk-junction solar cell consisting of a soluble poly[5-(3,7-dimethyloctyloxy)-1,4-phenylenvinylene]and a soluble fullerene 60 derivative. $^{3}$
\end{abstract}

We have examined the performance of organic solar cells with blended solid films of conjugated polymers as a chargetransporting material and dyes as light-harvesting compounds. We have reported that an enhanced photocurrent was observed for an $\mathrm{Al} /$ organic solid Schottky-barrier cell with a blended solid film of regioregular polythiophene and a dye such as a porphyrin or a merocyanine. ${ }^{4-8}$ However in the cell, the aluminum electrode was photocorroded under illumination. ${ }^{9}$

Recently, $\mathrm{p}-\mathrm{n}$ heterojunction solar cells composed of an inorganic semiconductor as an electron-transporting material and a conjugated polymer as a light-harvesting and hole-transporting compound have been studied. ${ }^{10-15}$ For example, Savenji et al. studied a solar cell consisting of a dense $\mathrm{TiO}_{2}$ thin film and poly[2-methoxy-5-(2'-ethyl-hexyloxy)-1,4-phenylene vinyl-

\footnotetext{
\# Division of Innovative Technology and Science, Graduate School of Natural Science and Technology, Kanazawa University
}

ene] MEH-PPV, ${ }^{10}$ Alevilsatos et al. studied a cell consisting of CdSe nano-rods and poly(3-hexylthiophene), ${ }^{11}$ and Carter et al. reported on a cell consisting of $\mathrm{TiO}_{2}$ nano-particles and poly[2-methoxy-5-(3',7'-dimethyl-octyloxy)-1,4-phenylene vinylene] MDMO-PPV. ${ }^{12}$ These types of solar cells were photostable, but the energy conversion efficiency was low due to the low light-harvesting ability of the conjugated polymer films.

We believe that combining both a blended solid and an inorganic semiconductor promises further improvement in solar cell performance. In this paper, we report an improvement in the photovoltaic properties of a $\mathrm{TiO}_{2} /$ regioregular poly(3-hexylthiophene-2,5-diyl)/Au sandwich-type solar cell sensitized with a merocyanine dye.

\section{Experimental}

Chemicals. Regioregular poly(3-hexylthiophene-2,5-diyl) (PTh, average molecular weight of ca. 87000) was purchased from Aldrich Chemicals and used without further purification. Merocyanine dyes MC1 and MC2 were purchased from Hayashibara Seibutsu Kagaku Lab. and used without further purification. The employed organic compounds and their abbreviations are shown in Fig. 1.

Preparation and Characteristics of $\mathrm{TiO}_{2}$ Electrode. Transparent $\mathrm{TiO}_{2}$ electrodes were prepared as follows: $0.5 \mathrm{~mL}$ of distilled water was added to $30 \mathrm{~mL}$ of anhydrous ethanol (Kanto Kagaku Co. Ltd.,) and adjusted to $\mathrm{pH} 1$ with concentrated $\mathrm{HNO}_{3}$. $4.26 \mathrm{~g}$ of titanium(IV) isopropoxide (Kanto Kagaku Co. Ltd.,) was added to this solution at room temperature under agitation. The solution was stirred at $40{ }^{\circ} \mathrm{C}$ for $16 \mathrm{~h}$. This $\mathrm{TiO}_{2}$ sol solution was then spin-coated on an $\mathrm{SnO}_{2}: \mathrm{F}$ substrate (Nippon Sheet Glass Co. Ltd., $<10 \Omega / \square$ ) at $2000 \mathrm{rpm}$. The sample was dried at $100{ }^{\circ} \mathrm{C}$ for $1 \mathrm{~h}$, then annealed at $450{ }^{\circ} \mathrm{C}$ for $1 \mathrm{~h}$. The process from the spin-coating to the annealing was repeated twice. 


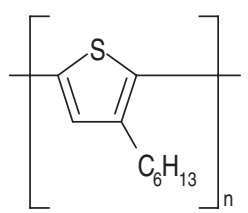

PTh

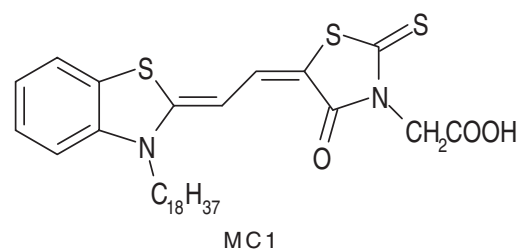<smiles>CN1C(=O)/C(=C\C=C2/Sc3ccccc3N2C)SC1=S</smiles>

Fig. 1. Structures of polythiophene and merocyanine dyes.

Cyclic voltammetry was carried out in an $\mathrm{N}_{2}$ purged acetonitrile solution containing $1 \mathrm{mM}$ ferrocene as a redox compound and 0.1 $\mathrm{M} \mathrm{Bu}_{4} \mathrm{NClO}_{4}$ as a supporting electrolyte at a scan rate of 100 $\mathrm{mV} \mathrm{s}^{-1}$. A $\mathrm{TiO}_{2}$ electrode or a $\mathrm{SnO}_{2}: \mathrm{F}$ electrode was used as the working electrode, a Pt coil as the counter electrode, and an $\mathrm{Ag}^{+} / \mathrm{Ag}$ electrode as the reference electrode. The surface morphology and the thickness of the $\mathrm{TiO}_{2}$ thin film on the $\mathrm{SnO}_{2}: \mathrm{F}$ substrate were observed with a Digital Instrument NanoScope III A atomic force microscope (AFM).

Measurement of Photovoltaic Characteristics. Figure 2 illustrates schematically the structure of the $\mathrm{TiO}_{2}$ /organic solid/ $\mathrm{Au}$ sandwich-type solar cell. The cell was fabricated as follows. First, the solid film of an organic insulator (Asahi Kagaku Lab., CR-30G-LL) was coated onto the $\mathrm{TiO}_{2}$ electrode by screenprinting. Then, the PTh $+\mathrm{MC}$ blended solid film was coated onto the $\mathrm{TiO}_{2}$ electrode by spin-coating. Finally, a gold electrode with a

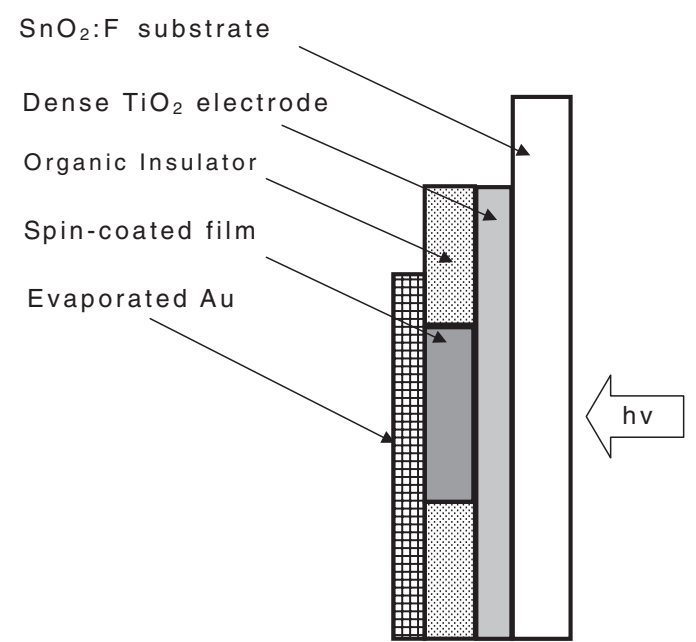

Fig. 2. Schematic structure of solar cell. thickness of about $25 \mathrm{~nm}$ was deposited onto the blended solid film by vacuum evaporation at $1 \times 10^{-4}$ Torr. The photoactive area was confined to $0.25 \mathrm{~cm}^{2}$. The thickness of the deposited Au film was monitored by an Ulvac CRTM-5000 oscillating quartz thickness controller, and the thickness $d$ and mixing ratio $R$ of the spin-coated organic solid film, which is defined by the molar ratio of MC to thiophene unit in PTh, were estimated from the amount and density of $\mathrm{MC}$ and PTh on the $\mathrm{TiO}_{2}$ electrode. The amount was determined by a Hitachi U-3310 UV-visible spectrometer after dissolving the MC and PTh in chloroform. The densities of both MC and PTh were assumed to be $1.3 \mathrm{~g} \mathrm{~cm}^{-3}$.

The photocurrent-voltage characteristics were measured using a simulated solar light source of AM1.5-100 $\mathrm{mW} \mathrm{cm}^{-2}$ at a scan rate of $500 \mathrm{mV} \mathrm{min}^{-1}$. The simulated solar light was obtained by a Kansai Kagakukikai XES-502S, and the light intensity was monitored by a SCIENTECH 365 power and energy meter.

The action spectra were measured at a scan rate of $60 \mathrm{~nm} \mathrm{~min}^{-1}$. The light source consisted of a $750 \mathrm{~W}$ halogen tungsten lamp, and a Jasco CT-10 monochromator with a scanning controller SDM-25C was used. The light intensity was monitored by an Advantest TQ8210 optical power meter with a silicon photocell. The photocurrent was measured by an Advantest R-8240 electrometer and was recorded by a Yokogawa Denki 3057 portable recorder.

For the measurement of the electrical resistance of solid films in the dark and under AM1.5 illumination, an Au/organic solid/Au surface-type cell was employed. The interdigitated Au electrode, with a $150 \mu \mathrm{m}$ gap and $207.7 \mathrm{~mm}$ long, was deposited on an alumina substrate before the spin-coating solid film was formed on it with a thickness of about $30 \mathrm{~nm}$. The resistivity was estimated from the slope of the current-voltage line obtained by applying a ramp bias of $10 \mathrm{~V}$ and simultaneously measuring current.

The electric capacitance accumulated at the $\mathrm{TiO}_{2} /$ organic solid interface was measured in the dark as a function of the applied voltage by a low-frequency oscillographic method using a triangle wave. $^{6}$ A Hokuto Denko electrochemical analyzer, HAG- $1512 \mu$ of the Hz-3000 series, was used for this measurement.

\section{Results and Discussion}

Characteristics of the $\mathrm{TiO}_{2}$ Electrode. Figure 3 shows cyclic voltammograms of the $\mathrm{TiO}_{2}$ electrode and the $\mathrm{SnO}_{2}:$ F electrode in an acetonitrile solution containing ferrocene, $\mathrm{Fc}$, as a redox compound. A pair of peaks for the redox reaction of Fc was observed for the $\mathrm{SnO}_{2}: \mathrm{F}$ electrode, but the redox reaction was not observed for the $\mathrm{TiO}_{2}$ electrode with about $100 \mathrm{~nm}$

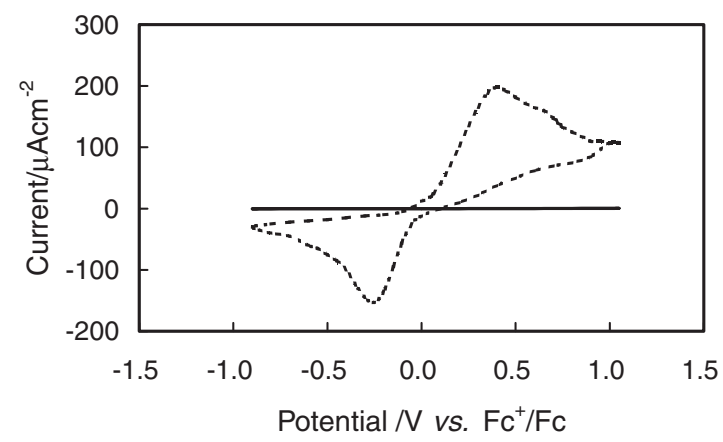

Fig. 3. Cyclic voltammograms for the $\mathrm{TiO}_{2}$ electrode (solid line) and $\mathrm{SnO}_{2}:$ F electrode (dotted line) in acetonitrile containing $1 \mathrm{mM}$ ferrocene and $0.1 \mathrm{M} \mathrm{Bt}_{4} \mathrm{NClO}_{4}$ as supporting electrolyte. Scan rate was $100 \mathrm{mV} \mathrm{s}^{-1}$. 

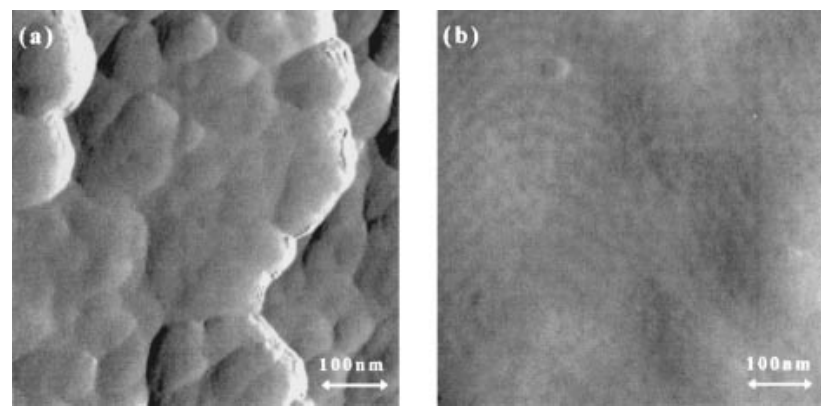

Fig. 4. AFM images of the $\mathrm{SnO}_{2}: \mathrm{F}$ electrode (a) and the $\mathrm{TiO}_{2}$ electrode (b).

thickness. When the $\mathrm{TiO}_{2}$ electrode was soaked in $3 \times 10^{-4}$ mol dm ${ }^{-3} \mathrm{MC} 1$ ethanol solution for $24 \mathrm{~h}, \mathrm{MC} 1$ was hardly adsorbed on the electrode despite of the carboxyl group in the MC1 molecule. On the other hand, many MC1 molecules were chemically adsorbed on a nano-porous $\mathrm{TiO}_{2}$ electrode because of its carboxyl group (see Ref. 16). Figure 4 shows AFM images of the $\mathrm{SnO}_{2}: \mathrm{F}$ electrode (a) as well as the $\mathrm{TiO}_{2}$ electrode on the $\mathrm{SnO}_{2}: \mathrm{F}$ substrate (b). The surface morphology of the $\mathrm{TiO}_{2}$ electrode was much flatter than that of the $\mathrm{SnO}_{2}: \mathrm{F}$ substrate. Further, the $\mathrm{TiO}_{2}$ electrode on the $\mathrm{SnO}_{2}: \mathrm{F}$ substrate was a non-porous film without cracks.

Photovoltaic Characteristics of the Solar Cells. We previously reported that a Schottky-barrier was formed at the interface between the low work function $\mathrm{Al}$ and solids with a p-type conductance of MC2 or PTh. ${ }^{6}$ The bottom energy level of the conduction band of $\mathrm{TiO}_{2}$ was $3.8-4.2 \mathrm{eV},{ }^{10,12,13}$ being nearly equal to the work function of $\mathrm{Al}$. Therefore a $\mathrm{p}-\mathrm{n}$ heterojunction or a Schottky barrier may be formed at the interface between $\mathrm{TiO}_{2}$ and MC or PTh.

Figure 5 shows current-voltage characteristics of PTh (a), MC1 (b), and MC1 + PTh (c) solar cells under an illumination of AM1.5-100 $\mathrm{mW} \mathrm{cm}^{-2}$. The dark current-voltage curve for the pure MC1 and PTh cells did not exhibit a clear rectification property. On the other hand, the dark current-voltage curve for the MC1 + PTh blend cell exhibited some rectification behavior. Photovoltaic properties such as the short-circuit photocurrent, $J_{\mathrm{sc}}$, open-circuit photovoltage, $V_{\mathrm{oc}}$, fill factor, $F F$, and energy conversion efficiency, $\eta$ under an illumination of AM1.5-100 $\mathrm{mW} \mathrm{cm}^{-2}$ are summarized in Table 1. The values of $J_{\mathrm{sc}}=1.9 \mu \mathrm{A} \mathrm{cm}^{-2}, V_{\mathrm{oc}}=175 \mathrm{mV}, F F=20.2 \%$, and $\eta=$ $7 \times 10^{-5} \%$ were obtained for the pure PTh solar cell. The values of $J_{\mathrm{sc}}=9.8 \mu \mathrm{A} \mathrm{cm}^{-2}, V_{\mathrm{oc}}=450 \mathrm{mV}, F F=28.3 \%$, and
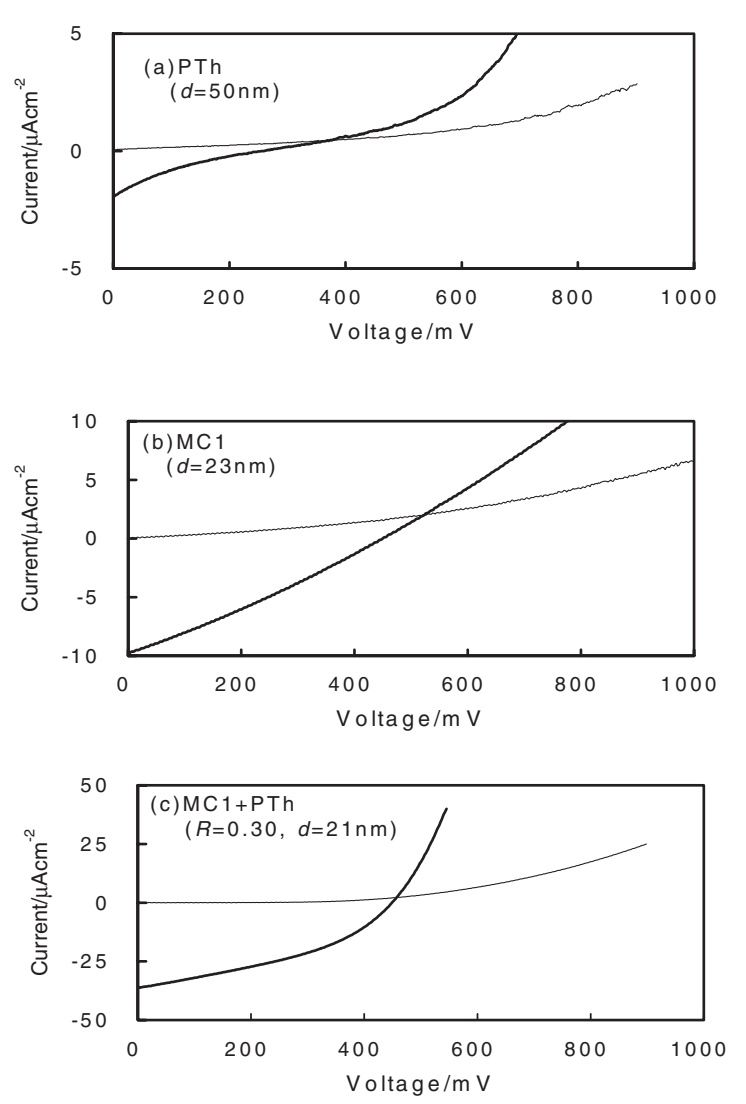

Fig. 5. Current-voltage characteristics of $\mathrm{TiO}_{2} /$ organic solid/Au sandwich-type solar cells with PTh (a), MC1 (b), and $\mathrm{MC1}+\mathrm{PTh}(\mathrm{c})$ under illumination of AM1.5-100 $\mathrm{mW} \mathrm{cm}^{-2}$ (thick line) and in the dark (thin line). $R$ is molar ratio of MC1 to thiophene unit in PTh, and $d$ is the film thickness.

$\eta=1.2 \times 10^{-3} \%$ were obtained for the pure MC1 solar cell. On the other hand, the higher values of $J_{\mathrm{sc}}=36.2 \mu \mathrm{A} \mathrm{cm}^{-2}$, $V_{\mathrm{oc}}=449 \mathrm{mV}, F F=39.5 \%$, and $\eta=6.4 \times 10^{-3} \%$ were obtained for the MC1 + PTh blended solar cell. The enhanced photovoltaic properties were also observed with the blend cell consisting of PTh and MC2, which does not have carboxyl group and long alkyl group. However, the $\eta$ value for the MC2 + PTh blend cell was smaller than that for the MC1 + PTh blended cell, due to non-uniformity in the MC2 + PTh blended film. The reason for the enhanced performance in the blended cells will be discussed later.

Table 1. Performance of $\mathrm{TiO}_{2} /$ Organic Solid/Au Sandwich-Type Solar Cells under AM1.5$100 \mathrm{~mW} \mathrm{~cm}^{-2}$ Illumination

\begin{tabular}{ccccccc}
\hline $\begin{array}{c}\text { Organic } \\
\text { solid }\end{array}$ & $R^{\mathrm{a})}$ & $\begin{array}{c}d^{\mathrm{b})} \\
/ \mathrm{nm}\end{array}$ & $\begin{array}{c}\left.J_{\mathrm{sc}}{ }^{\mathrm{c}}\right) \\
/ \mu \mathrm{Acm}^{-2}\end{array}$ & $\begin{array}{l}V_{\text {oc }}{ }^{\mathrm{d})} \\
/ \mathrm{mV}\end{array}$ & $F F^{\mathrm{e})}$ & $\begin{array}{c}\eta^{\mathrm{f}} \\
/ \%\end{array}$ \\
\hline PTh & 0 & 50 & 1.9 & 175 & 20.2 & $7.0 \times 10^{-5}$ \\
MC1 & - & 23 & 9.6 & 450 & 28.3 & $1.2 \times 10^{-3}$ \\
MC1 + PTh & 0.30 & 21 & 36.2 & 449 & 39.5 & $6.4 \times 10^{-3}$ \\
MC2 & - & 38 & 3.0 & 40 & 24.5 & $3.0 \times 10^{-5}$ \\
MC2 + PTh & 0.31 & 56 & 25.3 & 442 & 26.2 & $2.9 \times 10^{-3}$ \\
\hline
\end{tabular}

a) Molar ratio of merocyanine dye to thiophene unit in polythiophene. b) Film thickness. c) Short-circuit photocurrent density. d) Open-circuit photovoltage. e) Fill factor. f) Energy conversion efficiency. 

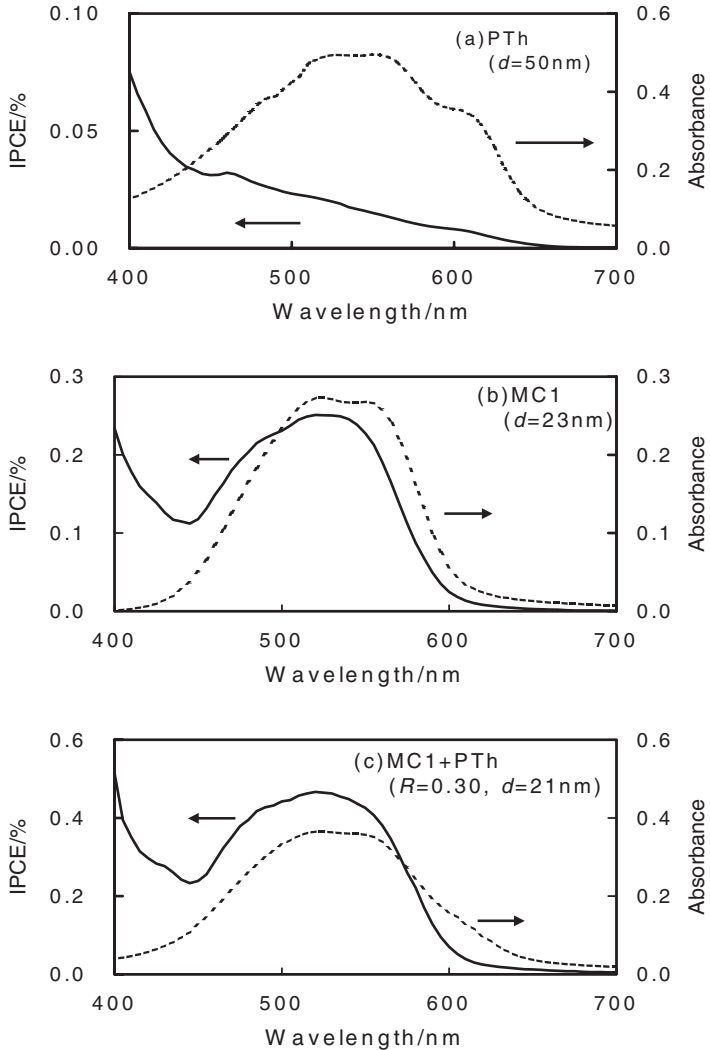

Fig. 6. Photocurrent action spectra of $\mathrm{TiO}_{2} /$ organic solid/ $\mathrm{Au}$ sandwich-type solar cells with PTh (a), MC1 (b), and $\mathrm{MC} 1+\mathrm{PTh}(\mathrm{c}) . R$ and $d$ indicate the mixing molar ratio and the film thickness, respectively, and IPCE is the incident photon to current conversion efficiency.

Figure 6 shows the short-circuit photocurrent action spectra of the PTh (a), MC1 (b), and MC1 + PTh (c) solar cells for the $\mathrm{TiO}_{2}$ side illumination, and absorption spectra of their films on a glass substrate. The direction of the photocurrent was from the $\mathrm{Au}$ electrode to the $\mathrm{TiO}_{2}$ electrode in the external circuit. Incident photon to current conversion efficiency, IPCE, was given by dividing the number of photo-generated electrons by the incident photon number. The action spectra resembled the absorption spectra. This indicates that the absorbed photons in the organic solid were employed for the photocurrent generation, and that the photoactive site was at the $\mathrm{TiO}_{2}$ /organic solid interface. The IPCE value for the MC1 + PTh blended cell was large compared to that for the pure MC1 or PTh solar cell. This indicates that the efficiency of the photocharge separation for the blended cell increased, increasing the $\eta$ value.

Figure 7 shows the dependence of the short-circuit photocurrent, open-circuit photovoltage, fill factor, and energy conversion efficiency in the MC1 + PTh blend cell on the thickness of the blended film. The $J_{\text {sc }}$ and $F F$ values increased up to a thickness of about $20 \mathrm{~nm}$, the $V_{\text {oc }}$ value increased up to about $10 \mathrm{~nm}$, and the $\eta$ value increased up to about $20 \mathrm{~nm}$. We cannot explain the inconsistency between the thickness dependence of $J_{\mathrm{sc}}$ and $V_{\mathrm{oc}}$. For an electric field formed at the $\mathrm{TiO}_{2} /$ organic solid interface, we will discuss later.

Only a mono-layer of MC1 has been chemically adsorbed on a $\mathrm{TiO}_{2}$ nano-porous electrode in the dye-sensitized solar cells,
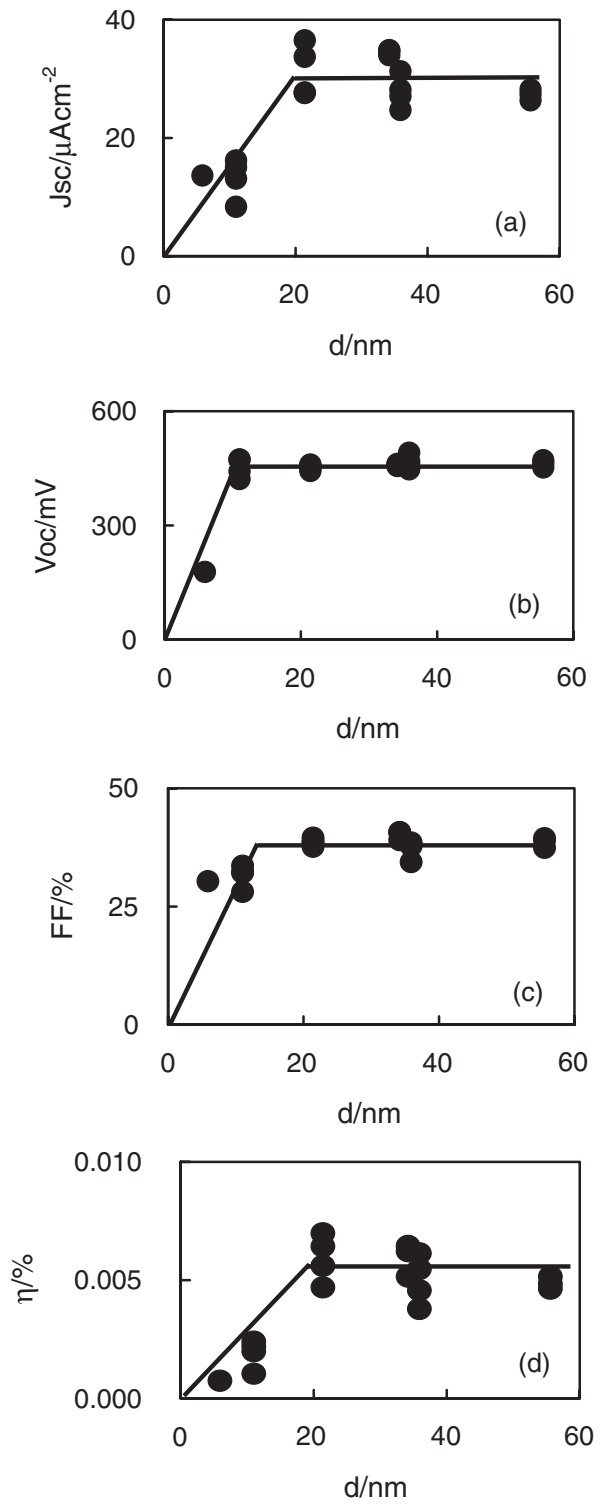

Fig. 7. Film thickness dependence of short-circuit photocurrent $J_{\text {sc }}\left(\right.$ a), open-circuit photovoltage $V_{\text {oc }}($ b), fill factor $F F$ (c) and energy conversion efficiency $\eta$ (d) under illumination of AM1.5-100 $\mathrm{mW} \mathrm{cm}^{-2}$ for the $\mathrm{MC1}+\mathrm{PTh}$ $(R=0.3)$ blended solar cell.

so-called Grätzel cell. ${ }^{16}$ On the other hand, since we used a dense and non-porous $\mathrm{TiO}_{2}$ electrode on which the $\mathrm{MC} 1$ molecules with a carboxyl group hardly adsorbed, the photocurrent generation mechanism for the blended cells may be different from that of Grätzel cells.

Effect of Photoinduced Charge Transfer. We previously reported that when a photoinduced hole-transfer occurred from the HOMO level of MC2 to the valence band of PTh in an $\mathrm{Al} /$ MC2 + PTh Schottky-barrier cell, the photovoltaic properties were improved. ${ }^{6}$ Since the HOMO levels of MC1 and MC2 are nearly equal, based on cyclic voltammetry in dichloromethane containing $\mathrm{MC} 1$ or $\mathrm{MC} 2$, photoexcited holes in $\mathrm{MC} 1$ can be injected in to the valence band of PTh. The photoproduced holes in PTh were transported to the Au electrode by the electric field formed at the interface of $\mathrm{TiO}_{2}$ and the blended 


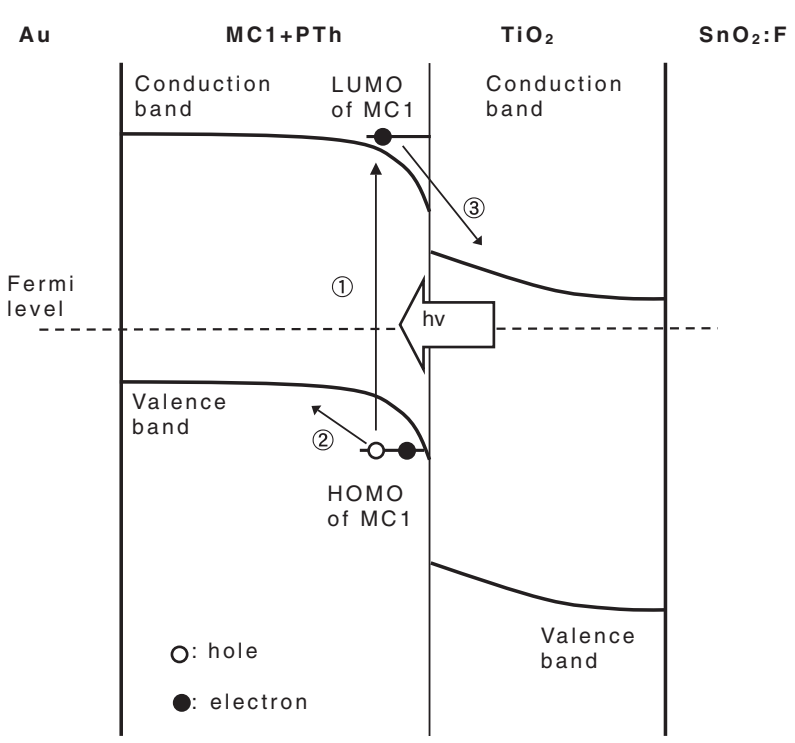

Fig. 8. Schematic energy diagram for $\mathrm{TiO}_{2} / \mathrm{MC} 1+\mathrm{PTh} /$ Au sandwich-type solar cell. See the text for the explanation of the sequence numbers (1), (2), and (3).

film, on the other hand, the photoproduced electrons arrived at the $\mathrm{TiO}_{2}$ electrode. This proposal of the photocurrent generation mechanism is shown in Fig. 8. First, MC1 in the blended solid is excited (process (1)). Second, the charge transfer occurs between the excited $\mathrm{MC} 1$ and the ground-state PTh (process (2). Finally, the resulting holes and electrons are transported to the $\mathrm{Au}$ and $\mathrm{TiO}_{2}$ electrodes, respectively (process (3). When discrete pairs of electrons and holes are produced by photoinduced hole-transfer from MC1 to PTh, the coulombic force between the electron and the hole is much smaller than that in the excited MC1 molecule because of the large distance. These results in photocharge separation in the blended solar cell proceeding more easily by the electric field formed at the interface of $\mathrm{TiO}_{2}$ and the organic solid.

Influence of the Series Electrical Resistance of the Solar Cell. The magnitude of the series electrical resistance of the solar cell is generally an important factor for determining the photovoltaic properties. The value estimated from the cur- rent-voltage characteristics in Fig. 5 was $2.6 \times 10^{4} \Omega \mathrm{cm}^{-2}$ for the PTh cell (a), $1.8 \times 10^{4} \Omega \mathrm{cm}^{-2}$ for the MC1 cell (b), and $1.0 \times 10^{4} \Omega \mathrm{cm}^{-2}$ for the MC1 + PTh blend cell (c) under an illumination of AM1.5-100 $\mathrm{mW} \mathrm{cm}^{-2}$, as summarized in Table 2. The order of the magnitude was $\mathrm{MC} 1+\mathrm{PTh}<$ $\mathrm{MC} 1<\mathrm{PTh}$, the solar cell with a smaller series resistance indicating a higher performance.

The specific resistivity of organic solid films is summarized in Table 3. Under illumination, the resistivity of $\mathrm{MC} 1$ was over $10^{9} \Omega \mathrm{cm}$, and that of PTh and MC1 + PTh was $9.3 \times 10^{5} \Omega \mathrm{cm}$ and $1.3 \times 10^{7} \Omega \mathrm{cm}$, respectively. Since the order of the specific resistivities was $\mathrm{MC} 1>\mathrm{MC} 1+\mathrm{PTh}>\mathrm{PTh}$, it can be said that the photovoltaic properties are not necessary influenced by this factor.

Electric Field Formed at the $\mathrm{TiO}_{2} /$ Organic Solid Interface. The electric capacitance, $C$, at the $\mathrm{TiO}_{2}$ /organic solid interface was measured in the dark as a function of the applied voltage by a low-frequency oscillographic method using a triangle wave. ${ }^{6}$ When the applied ramp bias increases, the observed current, $J_{+}$, is the sum of discharging and ohmic currents:

$$
J_{+}=C(\mathrm{~d} V / \mathrm{d} t)+V / r r
$$

where $V, \mathrm{~d} V / \mathrm{d} t$, and $r r$ are the applied voltage, the scan rate of the applied voltage, and the resistance, respectively. When the voltage decreases, the current, $J_{-}$, is the sum of charging and ohmic currents,

$$
J_{-}=-C(\mathrm{~d} V / \mathrm{d} t)+V / r r
$$

Combining the above two equations, the capacitance is expressed:

$$
C=\left(J_{+}-J_{-}\right) / 2(\mathrm{~d} V / \mathrm{d} t) .
$$

Further, because $\mathrm{d} V / \mathrm{d} t$ is equal to $4 V_{0} f$, where $V_{0}$ is the amplitude of the applied voltage and $f$ is the frequency of the ramp bias, the capacitance can be expressed as:

$$
C=\left(J_{+}-J_{-}\right) / 8 V_{0} f \text {. }
$$

When the current density is used for $J_{+}$and $J_{-}, C$ represents the capacitance per unit area. The insets of Fig. 9 show the currentvoltage curve under the application of a ramp bias between

Table 2. Series Resistance of $\mathrm{TiO}_{2} /$ Organic Solid/Au Sandwich-Type Solar Cells

\begin{tabular}{ccccc}
\hline Organic solid & $R$ & $d / \mathrm{nm}$ & \multicolumn{2}{c}{$R_{\text {int }}{ }^{\text {a) }} / \Omega \mathrm{cm}^{-2}$} \\
\cline { 3 - 5 } & & & in dark & under illumination \\
& & 70 & $6.1 \times 10^{5}$ & $2.6 \times 10^{4}$ \\
PTh & 0 & 23 & $2.3 \times 10^{5}$ & $1.8 \times 10^{4}$ \\
MC1 & - & 56 & $3.0 \times 10^{5}$ & $1.0 \times 10^{4}$ \\
\hline
\end{tabular}

a) Series resistance. b) Under AM1.5-100 $\mathrm{mW} \mathrm{cm}^{-2}$.

Table 3. Specific Resistivity of Organic Solid

\begin{tabular}{clccc}
\hline Organic solid & $R$ & $d / \mathrm{nm}$ & \multicolumn{2}{c}{$\rho^{\text {a) }} / \Omega \mathrm{cm}$} \\
\cline { 3 - 5 } & & & in dark & under illumination $^{\text {b) }}$ \\
\hline PTh & 0 & 43 & $1.4 \times 10^{6}$ & $9.3 \times 10^{5}$ \\
MC1 + PTh & 0.30 & 42 & $2.5 \times 10^{7}$ & $1.3 \times 10^{7}$ \\
\hline
\end{tabular}

a) Specific resistivity. b) Under AM1.5-100 $\mathrm{mW} \mathrm{cm}^{-2}$. 

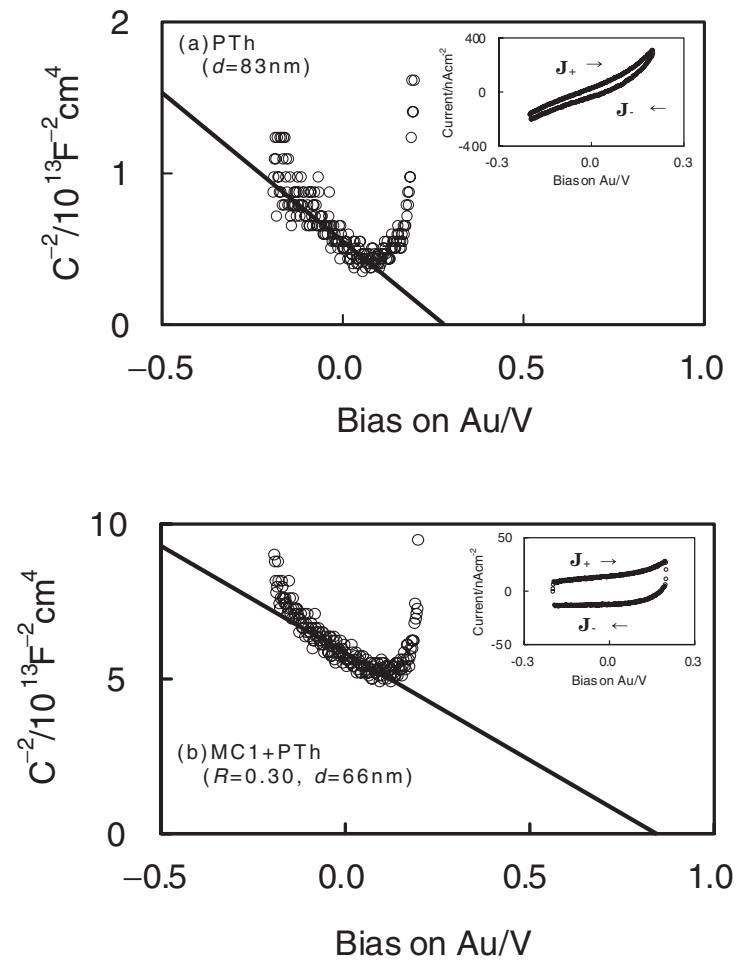

Fig. 9. Mott-Schottky plots of $\mathrm{TiO}_{2} /$ organic solid/Au sandwich-type solar cells with PTh (a) and MC1 + PTh (b). Insets show dark current-voltage curves at the frequencies of $94 \mathrm{mHz}$ (a), and $125 \mathrm{mHz}$ (b). The arrows in the insets show the direction of the potential sweep. See text for the definition of $J_{+}$and $J_{-}$.

-0.2 and $+0.2 \mathrm{~V}\left(V_{0}=0.2 \mathrm{~V}\right)$.

On the assumption that a $\mathrm{p}-\mathrm{n}$ hetero-junction is formed at the $\mathrm{TiO}_{2}$ /organic interface, Anderson's model was applied to analyze the electric profile at the interface, being employed for a $\mathrm{p}-$ $\mathrm{n}$ hetero-junction organic cell by Chamberlain. ${ }^{17}$ In this model, the capacitance is expressed as a function of the bias:

$$
\begin{aligned}
C^{-2}= & \left(\varepsilon_{\mathrm{n}} N_{\mathrm{p}}+\varepsilon_{\mathrm{p}} N_{\mathrm{n}}\right)^{2}\left(V_{\mathrm{b}}-V\right) \\
& /\left[\left(\varepsilon_{\mathrm{n}} N_{\mathrm{n}}+\varepsilon_{\mathrm{p}} N_{\mathrm{p}}\right) \varepsilon_{\mathrm{n}} \varepsilon_{\mathrm{p}} \varepsilon_{0} q N_{\mathrm{n}} N_{\mathrm{p}} A^{2}\right],
\end{aligned}
$$

where $\varepsilon_{\mathrm{n}}$ is the relative dielectric constant of an n-type semiconductor, $\varepsilon_{\mathrm{p}}$ is the relative dielectric constant of a p-type semiconductor, $\varepsilon_{0}$ is the vacuum permitivity, $q$ is the electron charge, $N_{\mathrm{n}}$ is the density of the ionized carrier in the n-type semiconductor, $N_{\mathrm{p}}$ is the ionized carrier density in the p-type semiconductor, $V_{\mathrm{b}}$ is the built-in potential of the $\mathrm{p}-\mathrm{n}$ heterojunction, and $A$ is the active area. The subscripts $\mathrm{n}$ and $\mathrm{p}$ represent $\mathrm{TiO}_{2}$ as the n-type semiconductor and the organic solid as the p-type semiconductor, respectively.
As shown in Fig. 9(a), the plot of $C^{-2}$ against $V$, a so-called Mott-Schottky plot, for the pure PTh cell gave a straight line in the range between -0.15 and $+0.05 \mathrm{~V}$. We obtained $V_{\mathrm{b}}=$ $0.25 \mathrm{~V}$. When $N_{\mathrm{p}}=6.0 \times 10^{17} \mathrm{~cm}^{-3},{ }^{6} \varepsilon_{\mathrm{p}}=4,{ }^{6}$ and $\varepsilon_{\mathrm{n}}=$ $48^{18}$ were used, the value of $1.7 \times 10^{17} \mathrm{~cm}^{-3}$ was obtained for $N_{\mathrm{n}}$. Following equations 6 and 7 , we obtained $W_{\mathrm{p}}=12$ $\mathrm{nm}, W_{\mathrm{n}}=51 \mathrm{~nm}$, where $W_{\mathrm{p}}$ and $W_{\mathrm{n}}$ represent the widths of the depletion layers in the p-type PTh and the n-type $\mathrm{TiO}_{2}$ under short-circuit conditions, respectively:

$$
\begin{aligned}
& W_{\mathrm{p}}=\left[2 N_{\mathrm{n}} \varepsilon_{\mathrm{n}} \varepsilon_{\mathrm{p}} V_{\mathrm{b}} /\left[q N_{\mathrm{p}}\left(\varepsilon_{\mathrm{n}} N_{\mathrm{p}}+\varepsilon_{\mathrm{p}} N_{\mathrm{n}}\right)\right]\right]^{1 / 2}, \\
& W_{\mathrm{n}}=\left[2 N_{\mathrm{p}} \varepsilon_{\mathrm{n}} \varepsilon_{\mathrm{p}} V_{\mathrm{b}} /\left[q N_{\mathrm{n}}\left(\varepsilon_{\mathrm{n}} N_{\mathrm{p}}+\varepsilon_{\mathrm{p}} N_{\mathrm{n}}\right)\right]\right]^{1 / 2} .
\end{aligned}
$$

Further, from Eqs. 8 and 9, we obtained $V_{\mathrm{bp}}=0.184 \mathrm{~V}$ and $V_{\mathrm{bn}}=0.066 \mathrm{~V}$, where $V_{\mathrm{bp}}$ and $V_{\mathrm{bn}}$ represent the built-in potentials in the p-type PTh and in the n-type $\mathrm{TiO}_{2}$ under short-circuit condition, respectively.

$$
\begin{aligned}
& V_{\mathrm{bp}} / V_{\mathrm{bn}}=\varepsilon_{\mathrm{n}} N_{\mathrm{n}} /\left(\varepsilon_{\mathrm{p}} N_{\mathrm{p}}\right), \\
& V_{\mathrm{b}}=V_{\mathrm{bp}}+V_{\mathrm{bn}} .
\end{aligned}
$$

Since the Mott-Schottky plot for the MC1 + PTh blend cell gave a straight line between -0.15 and $+0.10 \mathrm{~V}$, as shown in Fig. 9(b), we obtained $V_{\mathrm{b}}=0.620 \mathrm{~V}$ and $N_{\mathrm{p}}=6.9 \times 10^{17}$ $\mathrm{cm}^{-3}$ from Eq. 5 , and further $W_{\mathrm{p}}=20 \mathrm{~nm}, W_{\mathrm{n}}=80 \mathrm{~nm}, V_{\mathrm{bp}}=$ $0.613 \mathrm{~V}$, and $V_{\mathrm{bn}}=0.207 \mathrm{~V}$ from Eqs. 6, 7, 8, and 9, respectively. These parameters are summarized in Table 4 . The $W_{\mathrm{p}}$ value of the MC1 + PTh blend cell was nearly equal to the region of the photocurrent generation estimated from the thickness dependence of the photovoltaic properties in Fig. 7.

Under short-circuit conditions, the potential gradient $V_{\mathrm{bp}} / W_{\mathrm{p}}$ on the PTh side of the $\mathrm{TiO}_{2} / \mathrm{PTh}$ interface was $3.9 \times 10^{5}$ $\mathrm{V} \mathrm{cm}{ }^{-1}$, and $V_{\mathrm{bn}} / W_{\mathrm{n}}$ on the $\mathrm{TiO}_{2}$ side was $3 \times 10^{4} \mathrm{~V} \mathrm{~cm}^{-1}$. Further, for the MC1 + PTh blend cell, the values of $7.7 \times$ $10^{5} \mathrm{~V} \mathrm{~cm}^{-1}$ and $6 \times 10^{4} \mathrm{~V} \mathrm{~cm}^{-1}$ were obtained for $V_{\mathrm{bp}} / W_{\mathrm{p}}$ and the $V_{\mathrm{bn}} / W_{\mathrm{n}}$, respectively. Since the electric field on the organic solid side of both cells was much larger than that on the $\mathrm{TiO}_{2}$ side, this type of solar cell may be regarded as a $\mathrm{TiO}_{2} /$ organic solid Schottky barrier cell rather than a $\mathrm{p}-\mathrm{n}$ hetero-junction cell.

Since the value of the electric field on the organic solid side of both solar cells, MC1 + PTh $>$ PTh, agreeded with that of the energy conversion efficiency, $\eta$, to within on order of magnitude, there exists the opportunity to improve the photovoltaic properties.

\section{Conclusions}

In the $\mathrm{TiO}_{2} /$ organic solid/Au sandwich-type cells, the photovoltaic properties were much better for the MC1 + PTh blended cell than for the pure PTh cell. This is because an effective photoinduced hole-transfer occurred from the excited of

Table 4. Ionized Carrier Density $N$ in the Organic Solid, Built-in Potential $V_{\mathrm{b}}$ in $\mathrm{TiO}_{2} /$ Organic Solid/Au Sandwich-Type Solar Cells, and Depletion Layer Width $W$ at the $\mathrm{TiO}_{2} /$ Organic Solid Interface under Short-Circuit Condition

\begin{tabular}{ccccccccccc}
\hline & $R$ & $\begin{array}{c}d \\
/ \mathrm{nm}\end{array}$ & $\begin{array}{c}N_{\mathrm{p}} \\
/ 10^{17} \mathrm{~cm}^{-3}\end{array}$ & $\begin{array}{c}N_{\mathrm{n}} \\
/ 10^{17} \mathrm{~cm}^{-3}\end{array}$ & $\begin{array}{c}W_{\mathrm{p}} \\
/ \mathrm{nm}\end{array}$ & $\begin{array}{c}W_{\mathrm{n}} \\
/ \mathrm{nm}\end{array}$ & $\begin{array}{c}V_{\mathrm{bp}} \\
/ \mathrm{mV}\end{array}$ & $\begin{array}{c}V_{\mathrm{bn}} \\
/ \mathrm{mV}\end{array}$ & $\begin{array}{c}V_{\mathrm{bp}} / W_{\mathrm{p}} \\
/ 10^{5} \mathrm{~V} \mathrm{~cm}\end{array}$ & $\begin{array}{c}V_{\mathrm{bn}} / W_{\mathrm{n}} \\
/ 10^{5} \mathrm{~V} \mathrm{~cm}^{-1}\end{array}$ \\
\hline PTh & 0 & 83 & $6.0^{\mathrm{a}}$ & 1.7 & 12 & 51 & 184 & 66 & 3.9 & 0.3 \\
$\mathrm{MC1}+\mathrm{PTh}$ & 0.30 & 66 & 6.9 & 1.7 & 20 & 80 & 613 & 207 & 7.7 & 0.6 \\
\hline
\end{tabular}

a) From Ref. 6. 
MC1 to the ground-state of PTh, accelerating the photocharge separation in the depletion layer formed at the interface of $\mathrm{TiO}_{2}$ and $\mathrm{MC} 1+\mathrm{PTh}$. The depletion layer existed in the narrow region of about $20 \mathrm{~nm}$ on the organic solid side, and the electric field was about $8 \times 10^{5} \mathrm{~V} \mathrm{~cm}^{-1}$. That is, the blended solar cell in this work is not a so-called Grätzel cell being sensitized by mono-layer dyes chemically adsorbed on to a $\mathrm{TiO}_{2}$ electrode, but rather the enhanced photovoltaic properties are attributable to the dye-sensitization of the regioregular polythiophene.

We think further modifications of the conjugated polymer, sensitizer, and $\mathrm{TiO}_{2}$ electrode would increase the electric filed of the depletion layer or/and the thickness of the depletion layer. In fact, we recently obtained the photovoltaic properties of $J_{\mathrm{sc}}=814 \mu \mathrm{Acm}^{-2}, V_{\mathrm{oc}}=737 \mathrm{mV}, F F=56 \%$, and $\eta=0.33 \%$ under AM1.5-100 $\mathrm{mW} \mathrm{cm}^{-2}$ illumination in a new-type $\mathrm{TiO}_{2} / \mathrm{MC} 1+$ PTh blend solar cell fabricated with the $\mathrm{TiO}_{2}$ electrode prepared by a different method. This will be reported elsewhere in detail.

The authors are deeply indebted to Dr. K. Yase, Dr. K. Saito, Dr. N. Tanigaki, Dr. Y. Yoshida (National Institute of Advanced Industrial Science and Technology), and Miss C. Yokoe (Nippon Shokubai Co. Ltd.,) for their helpful discussion. This work was partially supported by Grant-in-Aid for Scientific Research from the Ministry of Education, Culture, Sports, Science and Technology (Grant 14580536), and by the new Energy and Industrial Technology Development Organization (NEDO) under Ministry of Economy, Trade and Industry (METI).

\section{References}

1 C. W. Tang, Appl. Phys. Lett., 48, 183 (1986).

2 M. Granstrom, K. Petritsch, A. C. Arias, A. Lux, M. R. Andersson, and R. H. Friend, Nature, 395, 257 (1998).

3 C. J. Brbec, S. E. Shaheen, C. Winder, and N. S. Sariciftci,
Appl. Phys. Lett., 80, 1288 (2002).

4 K. Takahashi, T. Goda, T. Yamaguchi, and T. Komura, J. Phys. Chem. B, 103, 4868 (1999).

5 K. Takahashi, T. Iwanaga, T. Yamaguchi, T. Komura, and K. Murata, Synth. Met., 123, 91 (2001).

6 K. Takahashi, K. Tsuji, K. Imoto, T. Yamaguchi, T. Komura, and K. Murata, Synth. Met., 130, 177 (2002).

7 K. Takahashi, M. Asano, K. Imoto, T. Yamaguchi, T. Komura, J. Nakamura, and K. Murata, J. Phys. Chem. B, 107, 1646 (2003).

8 K. Takahashi, I. Nakajima, K. Imoto, T. Yamaguchi, T. Komura, J. Nakamura, and K. Murata, Sol. Energy Mater. Sol. Cells, 76, 115 (2003).

9 K. Murata, S. Ito, K. Takahashi, and B. M. Holfman, Appl. Phys. Lett., 71, 674 (1997).

10 T. J. Savenije, J. M. Warman, and A. Goossens, Chem. Phys. Lett., 24, 148 (1998).

11 W. U. Huynh, J. J. Dittmerm, and A. P. Alevisatos, Science, 295, 2425 (2002).

12 A. C. Arango, L. R. Johnson, V. N. Bliznyuk, Z. Schlesinger, S. A. Carter, and H. H. Hörhold, Adv. Mater., 12, 1689 (2000).

13 Q. Fan, B. McQuillin, D. D. C. Bradley, S. Whitelegg, and A. B. Seddon, Chem. Phys. Lett., 26, 325 (2001).

14 C. D. Grant, A. M. Schwartzberg, G. P. Smestad, J. Kowalik, L. M. Tolbert, and Z. Zhang, Synth. Met., 132, 197 (2003).

15 P. A. van Hal, M. Wienk, J. M. Kroon, W. J. H. Verhees, L. H. Slooff, W. J. H. van Gennip, P. Jonkheijm, and R. A. J. Janssen, Adv. Mater., 15, 118 (2003).

16 K. Sayama, S. Tsukagoshi, K. Hara, Y. Ohga, A. Shinpou, Y. Abe, S. Suga, and H. Arakawa, J. Phys. Chem. B, 106, 1363 (2002).

17 G. A. Chamberlain, Mol. Cryst. Liq. Cryst., 93, 369 (1983).

18 M. Kiyono, “Sankatitan," Gihoudou, Tokyo (1991), p. 52. 